\title{
Indicators of deprivation, voting patterns, and health status at area level in the Republic of Ireland
}

\author{
C Kelleher, A Timoney, S Friel, D McKeown
}

J Epidemiol Community Health 2002;56:36-44

\begin{abstract}
Study objective: To determine what relation, if any, exists between mortality patterns, indicators of deprivation, general lifestyle and social attitudes, as exemplified by general election voting pattern, in the Republic of Ireland. A relation has been demonstrated previously between voting and mortality patterns in the United Kingdom.

Design: Cross sectional ecological study using three data sources. Standardised mortality ratios (SMR) were based on mortality rates at county level and 1996 census data from the Central Statistics Office, 1997 general election first preference voting data in all 41 constituencies were aggregated to county level. Selected reported measures of health status, lifestyle and social circumstances are from the first ever National survey on lifestyles, attitudes and nutrition (SLAN). This study comprised adults over 18 years sampled by post using the electoral register from 273 representative district electoral divisions. Univariate inter-relations were examined at individual level for the dataset as a whole, adjusting for age and at aggregated level for 26 county borough areas, which included the two largest cities and for 22 county areas, which afforded correlation with voting pattern, using the method of Pearson's correlation coefficient.

Participants: 1806932 votes were cast nationally at the 1997 general election, representing a voter turnout of $65.92 \%$. There was an overall response rate of $62 \%$ to SLAN comprising 6539 adults $147 \%$ male). The demographic pattern of survey respondents was consistent with that of the general population over 18 years.

Main results: At individual level there was a large number of highly significant inter-relations between indicators of deprivation, various measures of self rated health status and lifestyle factors. Aggregated at 26 county level percentage unemployed $(r=0.408, p=0.038)$, and level of education $(r=0.475$, $\mathrm{p}=0.014$ ) related significantly to $S M R$ and inversely to both fruit and vegetable consumption $(r=-0.672, p=0.001)$ and excess alcohol consumption among men $(r=-595, p=0.003)$. Those rating their health as fair or poor were more likely to report a poor quality of life $(r=0.487, p=0.022)$, to have none or primary school education only $(r=0.428, p=0.047)$, or to have a means tested medical services card $(r=0.428, p=0.047)$. There was no significant relation between SMR and voting pattern for the two main political parties (67.28\% first preferences) but a significant relation with left wing voting $(r=0.446, p=0.037)$. Fianna Fail voting pattern was inversely related to level of dissatisfaction with health $(r=-0.59, p<0.05)$. There was a positive significant relation between left wing voting and dissatisfaction with health $(r=0.51, p<0.02)$ and rate of smoking $(r=0.47, p=0.03)$. Smoking pattern also related positively to rates of voter abstention $(r=0.526, p=0.12)$.

Conclusions: These data are consistent with those in other countries in showing a relation between deprivation indicators and lifestyle, but differ in that no relation with SMR and the votes cast for the main parties was seen in a country with a mainly centre right voting pattern. The relation between left wing voting pattern and some indicators of deprivation and lifestyle suggest that party political voting patterns and affiliations could be a useful indicator of vertical social capital. However, its variability as a measure across countries suggests that the inter-relation between sociocultural and economic factors and the consequent influence on health status is not straightforward.
\end{abstract}

\begin{abstract}
$\Lambda^{1}$ though rates of coronary heart disease mortality in the Republic of Ireland rank among the highest in the developed world and there is relatively poor overall life expectancy compared with other European Union countries, ${ }^{1}$ little is known about the contribution of social variations to this pattern of ill health. Only a small number of area-based studies have examined this question ${ }^{23}$ and until a national survey on lifestyles, attitudes and nutrition (SLAN) was undertaken in 1999 no large scale nationally representative individual level risk factor datasets existed. ${ }^{4}$ What evidence we do have suggests that social variations in health status do exist however. ${ }^{5}$ Such variations are seen in some form in every country. Recent debate on the issue, either of general indicators like all cause mortality, or for specific conditions like cardiovascular disease, cancers, homicide or accidents has focused on both neo material ${ }^{6}$ or neo Durkheimian explana-
\end{abstract}

tions that take account of the psychosocial impact of relative inequality. ${ }^{7-9}$

While many indicators of material deprivation exist, there are fewer that might express sociopolitical attitudes, related more recently in health research to concepts of social cohesion or social capital that incorporate immediate family and social networks, as well as indicators of community and civil participation. ${ }^{10}{ }^{11}$ Contributions to this debate come mainly from larger, industrialised nations, making it difficult to disentangle the direct health effects of material deprivation from those symbolic of societal breakdown. This has not prevented policy shifts in relation to optimal strategies to promote population health. In recent years, more holistic, community development and settings based approaches have been adopted by international agencies like the World Health Organisation and many governments worldwide, even in 
tackling traditional individual level risk behaviours that are often class related, like smoking, alcohol consumption, and diet. $^{12}$ The combination of evidence is threefold. Firstly, individual level studies demonstrate the effectiveness of social support in reducing risk of heart disease and various forms of mental ill health. ${ }^{13}$ Secondly, in particular settings like the work environment there is persuasive evidence of the part played by social relations in influencing relative risk of ill health across social classes ${ }^{14}$ Most ambitious is the attempt to examine how a framework of social and economic structures at a macro level might have direct psychosocial consequences in society at large. ${ }^{8}$ This has translated into advocacy of more widespread exploitation of community networks to promote a sense of social capital, ${ }^{12}$ though there have been calls also for a broader conception that takes account of both horizontal but also vertical aspects of social networks and structures with a policy dimension, like local or central government. ${ }^{6}$

Usually voting pattern is used as a measure of social apathy or exclusion, as in the case of studies from the United States on degree of trust, which include indicators such as voter turnout. ${ }^{15}$ However, political affiliation in itself surely reflects social attitudes as it tells us what social policies people as individuals and groups support. In countries with continued representative rates of voter turnout this could be a useful indicator of social capital. The more intriguing question is whether it is the consequent social relations created or the policies in themselves that have a direct health impact. Davey Smith and Dorling ${ }^{16}$ showed a strong relation in the United Kingdom between voting patterns at constituency level for Conservative and Labour parties and mortality, and subsequent work in the United States ${ }^{17}$ and Russia ${ }^{18}$ indicated the same phenomenon but to a lesser degree. What therefore might be the pattern of relation between health status and voting where the political system is less clearly ideological along traditional left/right lines?

Ireland is a particularly relevant example in the context of the debate about deprivation and social capital. It is a country with high rates of morbidity and mortality, a long history of migration and economic disadvantage and yet has a strong tradition of social cohesion in some key respects like family support and church going ${ }^{19}$ and a political system that is not traditionally polarised along ideological lines. ${ }^{20}$ In this sense it is the possible exception in which to examine the rule. The objective of this study therefore was to see how self reported lifestyle, sociodemographic and health patterns within the national SLAN survey related at an area level to mortality and in turn how these indicators related to voting patterns.

\section{METHODS}

Three data sources were used in this study. Individual level data were included on selected variables collected as part of the national health and lifestyle survey SLAN in 1998. ${ }^{4}$ The methodology for that study, which has been described previously, involved a multistage cluster sample technique with random selection of individuals from the electoral register in 273 urban and rural district electoral divisions across the country so that information on a representative sample of people from each county equivalent area was available. Two questions relating to self reported quality of life and satisfaction with health, measured using a five point Likert scale, were taken from the quality of life instrument developed in 1993 by the World Health Organisation (WHOQoL). Self reported general health on a five point scale from excellent to poor was also recorded. Lifestyle practices were included in relation to current daily cigarette smoking, fruit and vegetable consumption of at least four items per day (the national target), and alcohol consumption of over 14 units per week in women and 21 units per week in men. Eligibility or not for general medical services, a means related system of entitlement to comprehensive health services, was recorded also. Level of deprivation was assessed in this study by means of three variables, private home ownership or otherwise, education from primary through to tertiary level and employment status, categorised in accordance with standard census questions.

Crude mortality rates are not available routinely from the Central Statistics Office at a level below that of county. In order therefore to calculate standardised mortality ratios (SMRs) a county equivalent level was decided upon. At this level it is possible to separate out Cork city and county into two and the greater Dublin area into four geographical distribution divisions. SMRs for these areas were then calculated using a standard indirect method based on mortality data of all adults over 18 years from the 1997 vital statistics report and denominator population data at county level from the 1996 census.

Electoral data from the 1997 general election data ${ }^{21}$ were used to establish percentage of first preference votes in each constituency. The voting system in Ireland, of proportional representation by the single transferable vote in multiple seat constituencies, has been said to promote a clientist, nonideological political system. The two largest parties in the Republic of Ireland, Fianna Fail and Fine Gael, have their origins in the Civil War that followed on the foundation of the State in 1922; Fianna Fail was founded in 1926 and Fine Gael in 1933. Neither party traditionally is notably ideological in economic terms, though both are regarded by analysts generally as being to the right of centre. ${ }^{20}$ The Labour party was established in 1912 and is a traditional socialist party, though seen to be to the ideological right of counterparts in Europe, including the British Labour party. There were two smaller ideological parties, not represented in all constituencies in general elections. The Democratic Left party arose from a strongly left wing Marxist Leninist background and is also the culmination of a series of breakaway splinters from a much earlier republican tradition. The Progressive Democrats, established in 1985, has a liberal market economy ethos and a relatively more liberal social agenda on issues like abortion and divorce.

There are 41 political constituencies in the Republic of Ireland, constituted according to a number of factors but principally population density, each returning between three and five deputies. Constituency borders may not necessarily relate to county borders or to public administration units. There are for instance 11 constituencies in Dublin city and county, five constituencies in the largest county, Cork, where the second largest city is located. Several of the larger counties have at least two constituencies, while some of the lower population density counties are paired into one constituency. The only way to achieve comparability between regional voting patterns and mortality rates was to treat each of the entire Dublin and Cork areas as one county and to retain as amalgamated units each constituency comprising two counties, giving 22 data points for this part of the analysis. The Progressive Democrats were represented in 15 of these areas only. Votes for the Labour party and Democratic Left (who coalesced into one party shortly after the general election) were taken together as one unit to indicate left pattern voting and were represented in 21 areas. There was a range of independent candidates and a number of other parties including the Greens, not a strong force at general elections; these were categorised together as others for this analysis. Proportion of abstainers for each constituency was calculated as the difference between eligible voters on the register and percentage turnout.

Simple univariate analyses were undertaken. Pearson's correlation coefficient was used to assess associations between variables, both at individual level in the SLAN dataset as a whole, where age adjusted partial correlation coefficients are reported and at aggregated level. Two area based matrices were assembled, first assessing SMR in relation only to the SLAN variables and therefore utilising the 26 area points with breakdown possible of the two largest population areas, Dublin and Cork and then including in addition the voting 


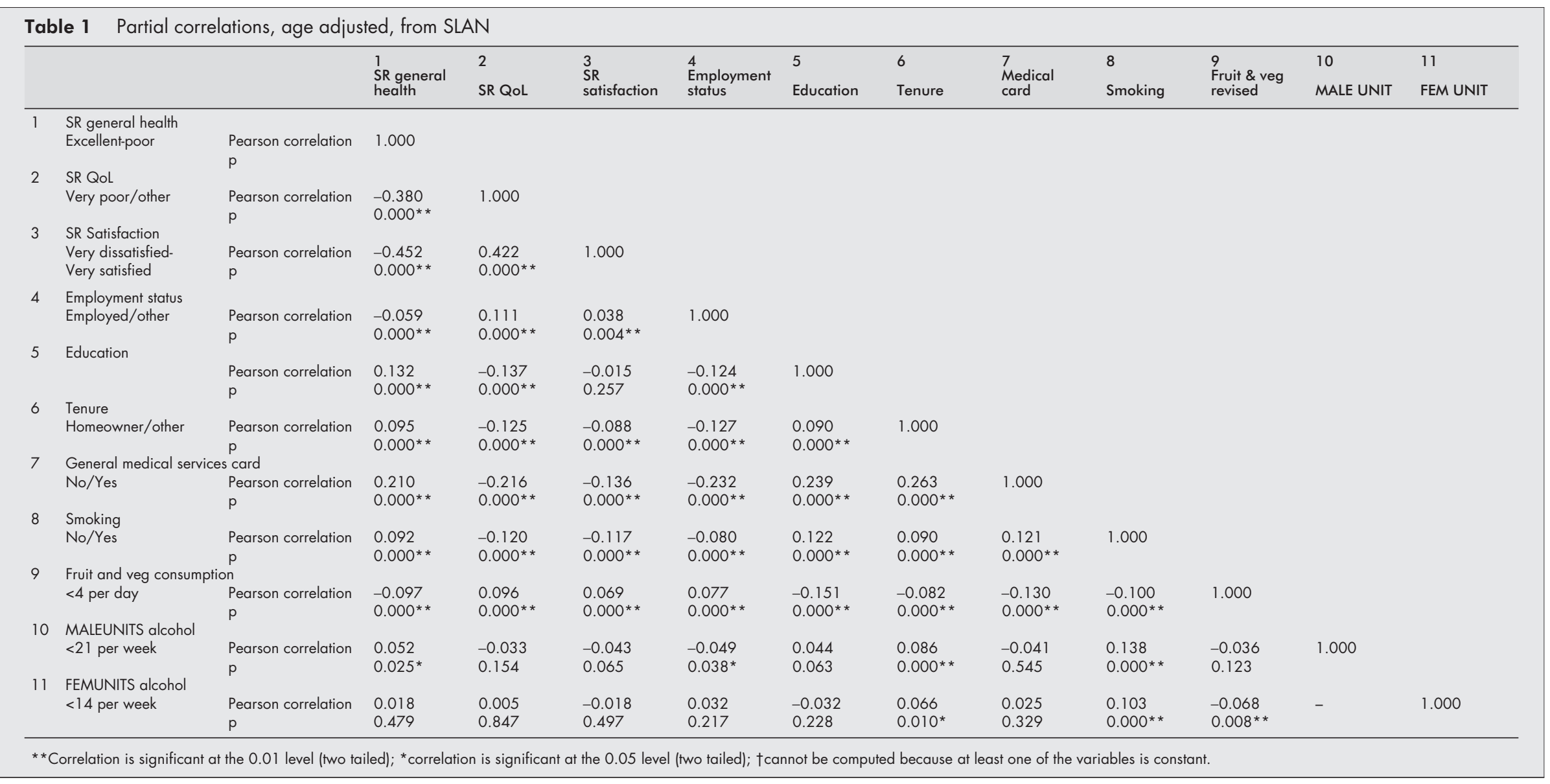




\begin{tabular}{|c|c|c|c|c|c|c|c|c|c|c|c|c|c|c|}
\hline & & \multirow[b]{2}{*}{$\begin{array}{l}\text { Standardised } \\
\text { mortality ratio }\end{array}$} & \multicolumn{3}{|c|}{ Indicators of deprivation } & \multicolumn{5}{|c|}{ Health status indicators } & \multicolumn{4}{|c|}{ Self reported lifestyle factors } \\
\hline & & & $\begin{array}{l}\% \\
\text { unemployed }\end{array}$ & $\begin{array}{l}\% \text { primary/ } \\
\text { no education }\end{array}$ & $\begin{array}{l}\% \text { home } \\
\text { owners }\end{array}$ & $\begin{array}{l}\% \text { GMS medical } \\
\text { card holders }\end{array}$ & $\begin{array}{l}\text { \% GMS medical } \\
\text { card holders } \\
<55 \text { years }\end{array}$ & $\begin{array}{l}\text { \% Self rated } \\
\text { health } \\
\text { fair/poor }\end{array}$ & $\begin{array}{l}\% \text { QoL very } \\
\text { poor/poor }\end{array}$ & $\begin{array}{l}\text { \% Dissatis/ } \\
\text { very dissatis. } \\
\text { health }\end{array}$ & $\begin{array}{l}\% \text { current } \\
\text { smokers }\end{array}$ & $\begin{array}{l}\% \text { fruit/veg } 4 \\
\text { or more per } \\
\text { day }\end{array}$ & $\begin{array}{l}\% \text { men }>21 \\
\text { units per } \\
\text { week }\end{array}$ & $\begin{array}{l}\text { \% women } \\
>14 \text { units } \\
\text { per week }\end{array}$ \\
\hline 1 & Westmeath & 110.70 & 8.00 & 20.00 & 86.00 & 22.30 & 16.00 & 9.10 & 2.10 & 9.60 & 33.30 & 51.60 & 29.60 & 28.60 \\
\hline 2 & Tipperary North & 111.03 & 7.00 & 27.00 & 76.70 & 45.80 & 37.00 & 14.20 & 2.60 & 7.10 & 22.90 & 55.40 & 7.40 & 20.80 \\
\hline 3 & Mayo & 97.67 & 8.00 & 30.00 & 81.00 & 41.60 & 31.00 & 15.50 & 6.70 & 10.70 & 23.60 & 58.90 & 22.80 & 20.00 \\
\hline 4 & Sligo-Leitrim & 108.03 & 6.00 & 24.00 & 77.60 & 25.60 & 21.00 & 16.60 & 4.50 & 10.50 & 32.10 & 65.90 & 22.20 & 10.70 \\
\hline 5 & Kerry & 99.59 & 4.00 & 19.00 & 78.30 & 26.20 & 19.00 & 11.00 & 3.00 & 12.10 & 25.10 & 69.00 & 28.60 & 26.70 \\
\hline 6 & Wexford & 108.06 & 6.00 & 30.00 & 86.40 & 33.10 & 24.00 & 18.20 & 4.20 & 7.40 & 22.60 & 56.40 & 18.50 & 18.80 \\
\hline 7 & Limerick & 107.77 & 6.00 & 30.00 & 78.90 & 29.40 & 19.00 & 20.30 & 8.40 & 14.20 & 25.40 & 55.60 & 31.70 & 26.80 \\
\hline 8 & Kildare & 109.46 & 9.00 & 30.00 & 78.70 & 33.60 & 24.00 & 13.90 & 2.70 & 12.40 & 35.80 & 56.20 & 17.20 & 23.90 \\
\hline 9 & Louth & 96.50 & 8.00 & 21.00 & 78.50 & 35.90 & 28.00 & 16.50 & 4.90 & 13.00 & 31.10 & 57.20 & 26.10 & 28.80 \\
\hline 10 & Carlow-Kilkenny & 103.45 & 3.00 & 20.00 & 84.90 & 22.00 & 16.00 & 10.40 & 3.39 & 9.70 & 27.20 & 61.20 & 32.00 & 31.10 \\
\hline 11 & Tipperary South & 105.83 & 8.00 & 30.00 & 68.90 & 42.50 & 41.00 & 17.20 & 8.30 & 11.70 & 28.20 & 57.60 & 33.30 & 40.00 \\
\hline 12 & Wicklow & 102.16 & 5.00 & 21.00 & 80.00 & 29.60 & 18.00 & 15.00 & 4.70 & 16.90 & 26.40 & 65.30 & 30.20 & 12.20 \\
\hline 13 & Longford-Roscommon & 98.04 & 6.00 & 24.00 & 89.50 & 41.40 & 29.00 & 18.50 & 2.00 & 6.00 & 23.70 & 60.30 & 29.70 & 16.10 \\
\hline 14 & Laois-Offaly & 95.71 & 7.00 & 25.00 & 80.90 & 30.20 & 18.00 & 13.90 & 2.60 & 10.40 & 25.40 & 59.00 & 22.00 & 11.10 \\
\hline 15 & Clare & 101.26 & 6.00 & 18.00 & 85.10 & 32.80 & 22.00 & 13.50 & 3.80 & 10.30 & 28.70 & 67.60 & 27.30 & 22.00 \\
\hline 16 & Waterford & 90.69 & 6.00 & 15.00 & 83.10 & 28.80 & 23.00 & 10.20 & 3.80 & 12.60 & 27.50 & 70.50 & 26.00 & 10.30 \\
\hline 17 & Donegal & 99.90 & 6.00 & 36.00 & 83.30 & 44.80 & 33.00 & 17.10 & 2.10 & 7.10 & 21.40 & 58.80 & 23.80 & 25.00 \\
\hline 18 & Galway & 95.15 & 4.00 & 23.00 & 83.00 & 32.80 & 21.00 & 16.80 & 3.90 & 9.10 & 22.10 & 63.20 & 23.20 & 22.70 \\
\hline 19 & Meath & 95.73 & 3.00 & 15.00 & 80.60 & 26.80 & 20.00 & 13.80 & 5.00 & 7.50 & 25.30 & 74.20 & 40.00 & 20.00 \\
\hline 20 & Cavan-Monaghan & 98.65 & 6.00 & 31.00 & 79.70 & 39.60 & 27.00 & 17.00 & 7.50 & 9.00 & 23.60 & 60.80 & 24.10 & 13.50 \\
\hline 21 & Dublin CoCorporation & 105.26 & 8.20 & 19.50 & 75.70 & 27.00 & 19.90 & 14.70 & 4.00 & 13.40 & 36.40 & 57.00 & 33.60 & 22.90 \\
\hline 22 & South Dublin & 86.17 & 3.90 & 10.80 & 86.30 & 13.00 & 9.30 & 10.20 & 3.50 & 14.90 & 37.40 & 59.50 & 26.40 & 16.40 \\
\hline 23 & Fingal & 83.93 & 2.60 & 9.00 & 80.50 & 17.90 & 16.40 & 12.70 & 1.90 & 11.50 & 30.80 & 64.20 & 26.20 & 22.90 \\
\hline 24 & Dunlaoghaire-Rathdown & 90.80 & 3.30 & 7.00 & 82.50 & 11.10 & 7.00 & 9.30 & 2.70 & 14.60 & 27.20 & 69.40 & 29.50 & 14.50 \\
\hline 25 & Cork County Borough & 123.67 & 4.60 & 19.00 & 84.60 & 28.10 & 21.80 & 15.10 & 3.10 & 10.90 & 35.40 & 61.50 & 28.80 & 18.40 \\
\hline 26 & Cork County & 100.87 & 4.80 & 16.80 & 78.10 & 27.10 & 18.20 & 11.60 & 3.30 & 8.70 & 26.10 & 66.70 & 29.50 & 18.40 \\
\hline
\end{tabular}


Table 3 Voting patterns at county level areas in the Republic of Ireland at General Election 1997, together with the percentage of votes cast for the different political parties in each of the areas and the percentage of abstainers

\begin{tabular}{|c|c|c|c|c|c|c|c|}
\hline Area & $\begin{array}{l}\text { Total votes } \mathrm{n}(\%) \\
\text { turnout }\end{array}$ & Fianna Fail \% & Fine Gael \% & $\begin{array}{l}\text { Labour/ Democratic } \\
\text { Left } \%\end{array}$ & $\begin{array}{l}\text { Progressive } \\
\text { Democrat \% }\end{array}$ & Others \% & $\begin{array}{l}\text { Abstainers } \\
\%\end{array}$ \\
\hline Westmeath & $33084(67.51)$ & 45.67 & 25.88 & 24.51 & NC & 3.94 & 32.49 \\
\hline Tipperary North & 40289 (74.76) & 42.29 & 11.32 & 10.33 & 3.48 & 32.59 & 25.24 \\
\hline Mayo & $62472(71.22)$ & 42.95 & 48.75 & NC & NC & 8.29 & 28.78 \\
\hline Sligo-Leitrim & $45618(70.43)$ & 40.41 & 36.63 & 10.86 & 1.65 & 10.45 & 29.57 \\
\hline Kerry & $71862(72.28)$ & 29.04 & 19.06 & 22.07 & NC & 29.83 & 22.79 \\
\hline Wexford & $56364(67.28)$ & 38.95 & 38.58 & 19.69 & NC & 2.79 & 32.72 \\
\hline Limerick & $84028(68.12)$ & 36.78 & 30.82 & 11.27 & 9.10 & 12.03 & 33.00 \\
\hline Kildare & $60864(60.73)$ & 35.37 & 26.33 & 24.18 & 9.96 & 3.36 & 39.28 \\
\hline Louth & $45611(64.16)$ & 40.02 & 27.90 & 10.50 & 5.32 & 16.27 & 35.84 \\
\hline Carlow-Kilkenny & $57140(67.15)$ & 42.19 & 29.19 & 15.19 & 5.64 & 7.80 & 32.85 \\
\hline Dublin & $470014(61.22)$ & 36.38 & 22.37 & 16.24 & 6.59 & 18.42 & 38.72 \\
\hline Cork & 213702 (68.37) & 39.54 & 34.37 & 11.06 & 3.51 & 11.16 & 32.44 \\
\hline Tipperary South & $35634(68.63)$ & 38.28 & 24.09 & 16.11 & $\mathrm{NC}$ & 22.52 & 31.37 \\
\hline Wicklow & $52730(65.54)$ & 29.87 & 19.71 & 23.79 & 3.3 & 23.33 & 34.46 \\
\hline Longford-Roscommon & $47843(74.82)$ & 47.02 & 36.91 & 1.48 & 4.84 & 9.75 & 25.18 \\
\hline Laois-Offaly & $58612(69.48)$ & 49.85 & 28.38 & 11.61 & 6.51 & 3.66 & 30.52 \\
\hline Clare & $47366(66.25)$ & 50.36 & 30.08 & 3.59 & 6.93 & 9.03 & 33.75 \\
\hline Waterford & $45464(65.14)$ & 35.79 & 24.55 & 11.77 & 6.46 & 21.43 & 34.86 \\
\hline Donegal & $68845(66.14)$ & 40.00 & 20.83 & 4.87 & $\mathrm{NC}$ & 34.30 & 33.84 \\
\hline Galway & 91980 (66.64) & 47.20 & 26.43 & 9.06 & 9.98 & 7.33 & 33.89 \\
\hline Meath & 57265 (63.54) & 41.88 & 36.92 & 7.93 & 2.37 & 10.9 & 36.46 \\
\hline Cavan-Monaghan & $60145(52.46)$ & 38.44 & 34.67 & 3.96 & & 22.93 & 27.54 \\
\hline
\end{tabular}

patterns, with Dublin and Cork treated as a single unit, and just 22 data points. There were insufficient area based data points for multivariate statistical assumptions to be satisfied in relation to the aggregated data.

\section{RESULTS}

The final response rate for SLAN was $62.2 \%$ and the total number of respondents was 6539 (47.0\% male). The overall correlation matrix confirmed a large number of highly significant relations, albeit some with rather low levels of correlation. When these were age adjusted the pattern remained the same except that the relation between employment status and education, previously direct, became inverse, suggesting age as a confounder. Table 1 illustrates the partial age adjusted correlation coefficients for all variables. Self rated general health, quality of life, satisfaction with health were all intercorrelated, and each related significantly to employment status, education, tenure, medical card possession, smoking status and fruit and vegetable consumption. Smoking rates were also significantly related to tenure and to medical card possession. This confirmed the appropriateness of examining patterns of inter-relation of these variables at an area level. The standardised mortality ratios in descending order for each of the 26 county borough areas are presented in table 2, together with the total percentages for each of the health, lifestyle and deprivation variables. This table shows some variation in SMR by county, ranging from a high of 123.67 in Cork county borough to a low of 83.93 in Fingal, an area of Dublin county. Likewise there was some variation in the other measures. Notably there are relatively high rates of home ownership throughout most of the country.

The total population at the 1996 census was 3526719 . Of 2714262 adults over 18 registered to vote, 1806932 votes were cast at the 1997 general election, representing a turnout of $65.92 \%$. Overall Fianna Fail obtained $39.33 \%$ of first preference votes, Fine Gael $27.95 \%$, Labour and Democratic Left combined $12.91 \%$, the Progressive Democrats $4.68 \%$ and others $15.13 \%$. The voting pattern in 22 county level areas, including turnout, is presented in table 3 . The correlations between voting patterns, standardised mortality ratios, eligibility for general medical services and the selected variables from SLAN are presented in table 4 . The higher the vote for Fianna Fail $(r=-0.534, \mathrm{p}=0.011)$ or Fine Gael $(r=$ $-0.630, p=0.002$ ) the lower the vote for left wing parties. There was no significant relation between mortality and voting pattern for either of the main parties, Fianna Fail and Fine Gael. The higher the Fianna Fail vote the higher was the percentage of homeowners $(\mathrm{p}=0.429, \mathrm{p}=0.046)$. There was a significant positive correlation $(r=0.446, \mathrm{p}=0.037)$ between combined left voting pattern and SMR. The higher the Fianna Fail vote the lower the rate of those dissatisfied with their health $(r=-0.578, \mathrm{p}=0.005)$. Conversely, Left wing voting patterns correlated significantly with dissatisfaction with health $(r=0.467, \mathrm{p}<0.028)$ and rates of regular smoking $(r=$ $0.470, \mathrm{p}=0.027)$. There were higher rates of regular smokers in constituencies with high rates of voting abstainers $(r=$ $0.526, \mathrm{p}<0.012)$. There was a significant negative relation between Left wing voting pattern and overall eligibility for general medical services $(r=-0.505, \mathrm{p}=0.017)$, which did not remain significant when only medical card holders under 55 years old were considered.

There was no relation between SMR and GMS eligibility. There were a number of other inter-relations at area level. For instance the higher the percentage rating their health fair or poor, the higher the proportion reporting a poor quality of life $(r=0.487, \mathrm{p}=0.007)$ none or primary education $(r=0.648$, $\mathrm{p}<0.001)$ and general medical services eligibility $(r=0.556$, $\mathrm{p}=0.007$ ). The percentage unemployed correlated significantly with level of education $(r=0.454, \mathrm{p}=0.034)$ and medical card ownership ( $r=0.428, \mathrm{p}=0.047)$. There was an inverse relation between percentage unemployed and both fruit and vegetable $(r=-0.672, \mathrm{p}=0.001)$ and excess alcohol consumption among males $(r=-595, \mathrm{p}=0.003)$. As it was not possible to relate SMRs to voting patterns for constituencies in the two larger cities we compared the correlation matrix for 26 areas with that for 22, to see whether the pattern of relationp between health status, deprivation or lifestyle indicators would be much altered generally. It was in fact almost identical, with the exception that percentage unemployed now related significantly to SMR $(r=0.408, \mathrm{p}=0.038)$ as did percentage with primary school education only $(r=0.454, \mathrm{p}=0.034)$, though the direction of the relation remained the same. 


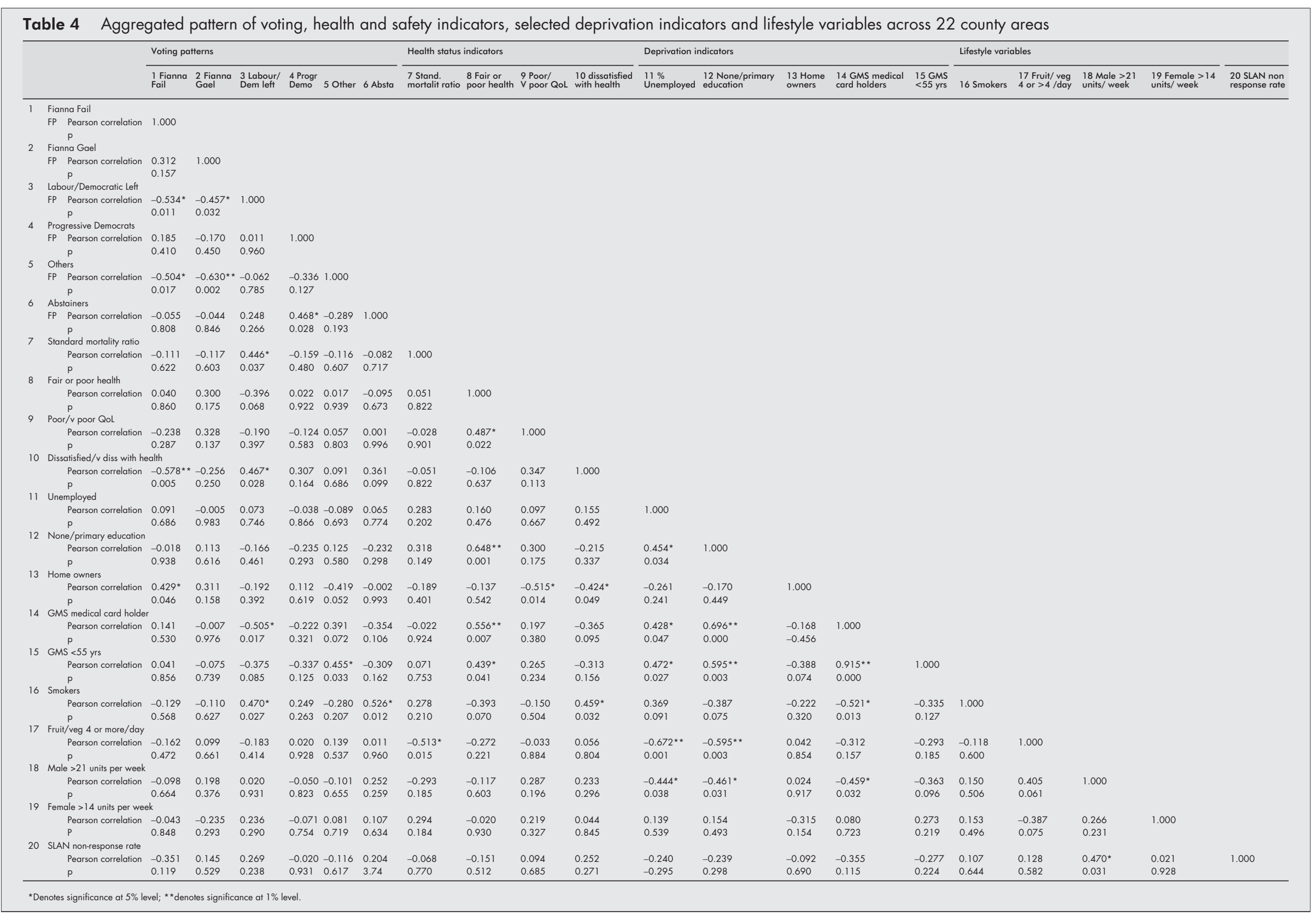

*Denotes significance at $5 \%$ level; * * denotes significance at $1 \%$ level 


\section{DISCUSSION}

In this study we combine for the first time, aggregated individual measures of self rated health and lifestyle, socioeconomic circumstances, personal and health service access with ecological level data on voting patterns and mortality.

\section{Relation between patterns of deprivation and health status in Ireland}

This study confirms at individual level in Ireland both the clear inter-relation between deprivation indicators such as level of education, housing tenure and rates of unemployment and in turn their correlation with lifestyle risk factors. Though little of the variance is explained, our purpose in this paper was to establish only that such relations existed in order to study the area patterns so no further detail is given at this stage. It is unknown how social class variations have contributed over the years to patterns of ill health in Ireland because of the lack of robust epidemiological data. What we do know from more recent work is that health inequalities do exist in Ireland $^{5}$ and that the country is now changing fast in socioeconomic terms. ${ }^{22}$ A clear social gradient in relation to health and lifestyle variables at individual level in this dataset for both men and women has already been reported. ${ }^{4}$

Despite the poor health profile of Irish people compared with their European counterparts, variation in mortality at county level is not as wide as is seen in other countries, like its close neighbour the United Kingdom and the relation with standard deprivation indicators is weak or inconsistent. There was some variation in the various indicators of self reported health status and lifestyle at area level. Certainly SMRs were higher in urbanised areas in particular but the relation with classic deprivation indicators like education and employment status was lost when the two large cities were absorbed to county level. This confirms in fact findings of the two previous studies of almost a decade ago. Johnson et al found a relation between deprivation and area SMRs within Dublin city. ${ }^{2}$ However, Howell et al found the pattern at county level was much weaker across the country as a whole and that the deprivation index used, a modification of that of Townsend did not relate to SMR. ${ }^{3}$ One explanation is the inappropriateness of the measure in a country with high levels of home ownership of varying standards and an education system reformed beyond recognition in the past 30 years..$^{22}$ In fact the inverse relation between education and unemployment in the dataset as a whole is explained by the fact that older people are more likely to have primary school education only and younger people to be unemployed. The geographical scale of the county and the relatively low population density may also be a problem. Yet there are coherent sociological reasons for considering area variations at this level, in that local government operates at a county level, regional health boards are comprised of counties and there is a strong county affinity exemplified by sporting organisations like the Gaelic Athletic Association.

\section{Voting pattern and health}

There was some evidence of a relation between left wing voting and SMR and of indicators of adverse lifestyle and deprivation, yet the voting pattern was relatively inconsistent and nothing like that of the United Kingdom. The important finding however is the fact that there is no relation with right wing or centrist voting. This is explicable mainly because of the lack of class polarisation in party political affiliation, which is clientist and often personality based. To an extent this reflects the proportional representation system but the proportion of the total population supporting the two main centrist parties is enormous, so it is not a matter of a failure of power to detect a significant relation. What do these findings signify about the association between voting pattern and health status? The original study by Davey Smith and Dorling ${ }^{16}$ was an assertion

\section{Key points}

- Both at individual and at area level there is a relation between measures of deprivation, lifestyle and health status in the Republic of Ireland.

- Standardised mortality ratio relates to deprivation measures only when inner city areas are discriminated in the analysis and not in the country as a whole.

- Party political affiliation is a potentially useful and subtle measure of vertical social capital, as it reflects both sociopolitical attitudes and their policy consequences and has now been demonstrated to relate to health status in several countries. However a new concept of citizenship might be the most appropriate public health strategy, rather than the presently used indicators.

- This study shows a significant relation between left wing voting, SMR, dissatisfaction with health and smoking status. However, it also shows a continuing level of social homogeneity in voting pattern in Ireland by the majority of people. This is in the face of high rates of ill health relative to other countries and despite the prevalence of features usually associated with social cohesion like high church attendance and tight knit family structures.

- The likelihood that health inequalities will widen in Ireland, despite economic growth, due to increasing urbanisation, suggests the appropriateness of direct measures to reduce income inequality and the impact of deprivation, rather than a more holistic social cohesion approach.

that voting patterns could be interpreted as a proxy for material circumstances in the different constituencies in the United Kingdom, and that the attitudes reflected in voting were a result of complacency about the provisions of the Welfare State among voters in the more affluent constituencies. In a follow up study on the 1997 election they found similar strong positive relations between SMRs and Labour party voting and the converse for the Conservative party. ${ }^{23}$ As quoted by Sinnott, ${ }^{20}$ voters in Ireland have consistently ranked themselves in the centre or to the right of centre in their political attitudes. The spectrum of difference between the Irish Labour party and Fianna Fail and Fine Gael, both remarkably similar to each other and closer to British Conservatives, was much narrower than the expressed differences in the United Kingdom between Labour and the Conservatives. This may well help to explain the less polarised relation between voting pattern and health status in Ireland compared with Britain.

\section{Social capital, deprivation, and voting pattern}

However, there may be a much wider debate on what voting patterns signify, to do with concepts of social capital and cohesion, as patterns in other countries are also seen but not in the same straightforward way. A number of studies in the United States assert relations between measures of social inequality, level of voting, and ill health. ${ }^{152}$ Kondrichin and Lester ${ }^{17}$ analysed the Reagan/Carter presidential election pattern in the United States, finding a negative correlation between mortality rate and the Republican vote. The same authors ${ }^{18}$ also analysed patterns in Russia at the 1993 election, finding an inverse relation between crude death rates and the percentage vote for the new constitution but not with the percentage voting for the Communist party. The combination of perceived dissatisfaction with health among those who are left voting and the converse for the majority party that we found suggests at least some psychosocial as well as material aspect to disadvantage. A majority of respondents were satisfied with their health in the SLAN survey and in this analysis that translated into satisfaction with their health on the part of Fianna Fail voters, the majority party. However the interrelation between economic inequality, the sociopolitical systems that bring that about or fail to address it and the impact on individual wellbeing is not straightforward. In the 
United States where economic and political structures are comparable in the country as a whole, even if income distribution varies greatly, ${ }^{9}$ cross state comparisons may well reflect relative discontent with material disadvantage but how true is that of less politically polarised and arguably more socially cohesive societies?

It is beyond the scope of this paper to address what explains these patterns but there is some relevant evidence. The social history of Ireland in the time since it became an independent republic is one of considerable general economic hardship and migration right up to the 1980s, and yet with strong indicators of so called social cohesion including tight knit family structures, high rates of church going and a socially conservative mainly rural culture. Analysis, for instance, of religious practices show the Irish as among the most consistent church going Christians anywhere. Nor has this waned as much as might be expected. Indeed, even though there has been strong dissent in recent years from the position of the Roman Catholic church on matters of private sexual practice and challenges to its authority generally, Christian values remain strong, even among the young. ${ }^{19}$

Furthermore, Ireland has long been known as a European oddity in the low level of political left wing support it enjoys. ${ }^{20}$ By the 1980 s a new class structure more typical of other European countries was in place. Party political allegiances were fairly constant in the past 30 years, Fianna Fail attracting a majority support of all social classes, Fine Gael being relatively more middle class and the Labour party having more working class support but also, like the others, receiving support across all classes. Although the emergence of a more ideological political system may be associated with signs of urban deprivation and a widening of the gap between rich and poor, traditional social and political values continue to be relatively important in the country as a whole. Yet this level of social consensus has apparently not translated into a better health profile, either in the past or in terms of contemporary health, based on these data.

\section{Methodological issues}

Though SMR data could not be related to voting pattern at constituency level in the cities we were able to compare the SLAN indicators at that level and hence indirectly assess whether deprivation would polarise patterns more. This suggests the effect of the relation between voting pattern and SMR may have been weakened for those inner city areas where absolute deprivation is greatest, but not greatly. Even there the rate of support for Fianna Fail is relatively strong. The indicator of both potential morbidity and possible disadvantage, eligibility for comprehensive general medical services related inversely with left wing voting, and not at all to SMR, which on the face of it is surprising as the scheme is means tested. However eligibility also relates strongly to age, which is likely to be the explanation here, given the fact that the pattern was much weaker for those less than 55 years of age and it is likely also that shifts in party political allegiance are due to more young people deserting the traditional parties. We have to be cautious in interpreting these lifestyle data because the sample for SLAN is necessarily smaller than for either voting data or SMRs and hence some of the variations seen may be due to lack of statistical precision rather than real between county variations. Furthermore, we do not have individual level data on voters' health profile. There were trends that could be explained by demographic patterns of party support including gender and age as well as class but these did not reach statistical significance. The study necessitated multiple variables in relatively few area points, so that there was arguably insufficient power to assess whether quite strong correlations were significant and also the possibility of statistically significant but incoherent correlations. We tackled this in two ways. Though this paper primarily relates to area patterns we included the individual level correlations to be sure that there were genuine inter-relations between deprivation indicators and lifestyle. The pattern was coherent and consistent with the findings in other countries in the overall data that have more power and precision. Furthermore the aggregated findings accord broadly with those of the one previous comparable study. ${ }^{3}$ The methodological problems in this study are common to many small countries and while they need to be acknowledged they are in themselves a good explanation as to why this debate is dominated by large scale data from highly populated industrialised countries.

\section{CONCLUSIONS}

This study has importance for the international debate on social capital and deprivation. The simple fact is that social breakdown coexists with poverty, deprivation, adverse lifestyle and poor health outcome in most industrialised countries, making an assessment of the relative contribution and causal directions of these inter-relations highly problematic. Physical measures of social capital cited to date might not necessarily be reflected in actual economic disparities and more importantly might not in themselves reflect the true underlying attitudes people have towards each other. This is why Ireland is a good example. In a small country with a complex proportional representation system mainstream party voting tells us what social and economic policies most voters are happy to support. Furthermore, social variations in the country as a whole are as marked at individual as area level across most of the country. On the strength of these data at least, the case for a macro-level shift in public policy rests securely on its direct impact on material disadvantage and empowerment of the poor, rather than a promotion of a politically cohesive consensus approach in itself. The findings suggest also that a more subtle conception of social capital is needed to explain or tackle health variations.

\section{ACKNOWLEDGEMENTS}

We are grateful to Professor Michael Laver, Trinity College Dublin for early advice on means of accessing voting data, to Dr Eamon O'Shea of the Department of Economics, NUI Galway and Dr Hanno Ulmer, University of Innsbruck, for helpful comments on the area level analyses.

Funding: The Survey on Lifestyle, Attitudes and Nutrition (SLAN), was funded by the Health Promotion Unit of the Irish government's department of Health and Children. Cecily Kelleher is the principal investigator of an inter-departmental Unit on Health Status and Health Gain, which is being funded over five years by the Health Research Board of Ireland.

Conflicts of interest: none.

\section{Authors' affiliations}

C Kelleher, S Friel, Department of Health Promotion, Clinical Science Institute, National University of Ireland, Galway, Republic of Ireland

A Timoney, Ballsbridge, Dublin, Republic of Ireland

D McKeown, Department of Public Health, Western Health Board, Merlin Park Hospital, Galway

\section{REFERENCES}

1 Department of Health and Children. Building Healthier Hearts. The report of the Cardiovascular Strategy Group. London: Stationery Office. 1999.

2 Johnson Z, Lyons R. Socio-economic factors and mortality in small areas. Ir Med J 1993:86: 60-2.

3 Howell F, O'Mahony M, Devlin J, et al. A geographical distribution of mortality and deprivation. Ir Med J 1993;86:96-9.

4 Friel S, Nic Gabhainn S, Kelleher C. Results of the National Health and Lifestyles Surveys in the Republic of Ireland, SLAN and HBSC. Department of Health and Children, Dublin and Centre for Health Promotion Studies, Galway, 1999. 
5 O'Shea E, Kelleher C. Health Inequalities in Ireland. In: Social spending, poverty and inequality in Ireland. Combat Poverty Agency. Dublin: Oak Tree Press, 2001:263-300

6 Lynch J, Due P, Muntaner C, et al. Social capital-Is it a good investment strategy for public health? J Epidemiol Community Health 2000:54:404-8

7 Wilkinson RG. Inequality and the social environment: a reply to Lynch et ale J Epidemiol Community Health 2000;54:41 1-13.

8 Wilkinson RG. Health inequalities. The afflictions of society. London: Routledge, 1996.

9 Kennedy BP, Kawachi I, Glass R, et al. Income distribution, socioeconomic status, and self rated health in the United States: multilevel analysis. BM 1998;317:917-21.

10 Baum F. Social capital: is it good for your health? Issues for a public health agenda. J Epidemiol Community Health 1999:53:195-6.

11 Kawachi I, Colditz GA, Ascherio A, et al. A prospective study of social networks in relation to total mortality and cardiovascular disease in men in the USA. J Epidemiol Community Health 1996;50:245-51.

12 Kelleher CC. Theories, values and paradigms: reflections on the fourth world conference on health promotion in Jarkarta. In: Edmondson $\mathrm{R}_{\text {, }}$ Kelleher $\mathrm{C}$, eds. Health promotion, new discipline or multidiscipline? Dublin: Irish Academic Press, 2000.

13 Berkman LF. Role of social-relations in health promotion. Psychosom Med 1995:57:245-54

14 Siegrist J. Place, social exchange and health: proposed sociological framework. Soc Sci Med 2000;51:1283-93.
15 Kawachi I, Kennedy BP. Health and social cohesion: why care about income inequality? In: Kawachi I, Kennedy BP, Wilkinson RG, eds. The society and health population reader. Income inequality and health. New York: The New Press, 195-201.

16 Davey Smith G, Dorling D. 'I'm alright John': Voting patterns and mortality in England and Wales. BMU 1996;313:1573-7.

17 Kondrichin SV, Lester O. Voting conservative and mortality. Percept Mot Skills 1998;87: 466.

18 Kondrichin SV, Lester O. 'I'm alright, Jack' in Russia too. Percept Mot Skills 1999:88:892

19 Greeley AW, Ward C. How secularised is the Ireland we live in? Doctrine and Life 2000;50:581-617.

20 Sinnott R. Irish voters decide. Voting behaviour in elections and referendums since 1918. Manchester: Manchester University Press, 1995.

21 Nealon T. Nealon's guide to the 28th Dail \& Seanad: Election 1997. Dublin: Gill and Macmillan, 1997.

22 Kelleher C. Health and the Celtic Tiger: progress of health promotion in modern Ireland. Health Education Research 1999;14:151-4.

23 Davey Smith G, Dorling D. Association between voting patterns and mortality remains. [Letter]. BM 1997;315:430-1.

24 Kawachi I, Kennedy BP, Gupta V, et al. Women's status and the health of men and women: a view from the States. Originally published in Soc Sci Med 1998. In: Kawachi I, Kennedy BP, Wilkinson RG, eds. The society and health population reader. Income inequality and eealth. New York: The New Press, 1999:474-91.

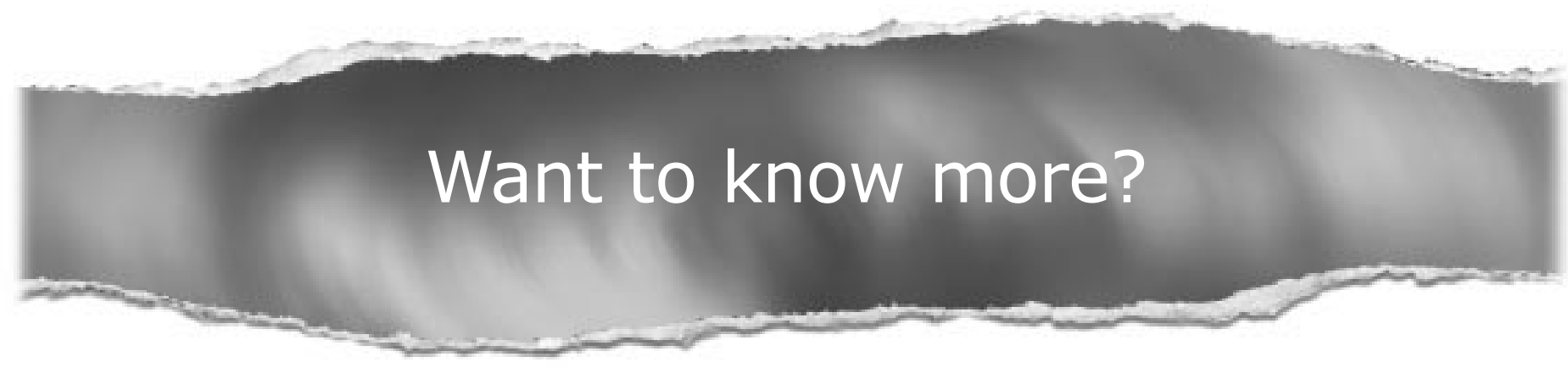

Data supplements

Limited space in printed journals means that interesting data and other material are often edited out of articles; however, limitless cyberspace means that we can include this information online. Look out for additional tables, references, illustrations.

www.jech.com 